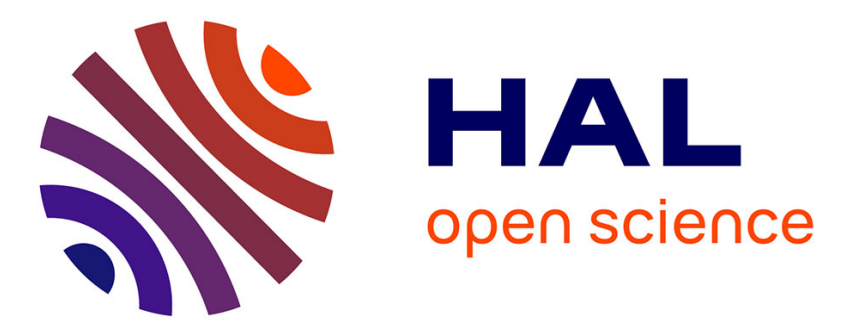

\title{
Influence of Pluronic 85 and ketoconazole on disposition and efficacy of ivermectin in sheep infected with a multiple resistant Haemonchus contortus isolate
}

Dj Bartley, A.A Morrison, Jacques Dupuy, Y Bartley, Jean-Francois Sutra, Cécile Menez-Berlioz, Roger Alvinerie, F Jackson, L. Devin, Anne Lespine

\section{To cite this version:}

Dj Bartley, A.A Morrison, Jacques Dupuy, Y Bartley, Jean-Francois Sutra, et al.. Influence of Pluronic 85 and ketoconazole on disposition and efficacy of ivermectin in sheep infected with a multiple resistant Haemonchus contortus isolate. Veterinary Parasitology, 2012, 187 (3-4), pp.464-472. 10.1016/j.vetpar.2012.02.011 . hal-01222889

\section{HAL Id: hal-01222889 \\ https://hal.science/hal-01222889}

Submitted on 19 Nov 2015

HAL is a multi-disciplinary open access archive for the deposit and dissemination of scientific research documents, whether they are published or not. The documents may come from teaching and research institutions in France or abroad, or from public or private research centers.
L'archive ouverte pluridisciplinaire HAL, est destinée au dépôt et à la diffusion de documents scientifiques de niveau recherche, publiés ou non, émanant des établissements d'enseignement et de recherche français ou étrangers, des laboratoires publics ou privés. 


\title{
Influence of Pluronic 85 and ketoconazole on disposition and efficacy of ivermectin in sheep infected with a multiple resistant Haemonchus contortus isolate
}

\author{
D.J. Bartley ${ }^{a}$, , A.A. Morrison ${ }^{a}$, J. Dupuy ${ }^{b}$, Y. Bartley ${ }^{a}$, J.F. Sutra ${ }^{b}$, C. Menez ${ }^{b}$, M. Alvinerie ${ }^{b}$, \\ F. Jackson ${ }^{a}$, L. Devin ${ }^{a}$, A. Lespine ${ }^{b}$ \\ a Moredun Research Institute, Pentlands Science Park, Bush Loan, Penicuik, EH26 OPZ, UK \\ b INRA UMR1331, Université de Toulouse III, INP, TOXALIM, F-31027 Toulouse, France
}

\section{A R T I C L E I N F O}

Article history:

Received 24 October 2011

Received in revised form 13 February 2012

Accepted 19 February 2012

\section{Keywords:}

Haemonchus contortus

Ivermectin

Ketoconazole

P-glycoprotein

Efficacy

Pluronic P85

\begin{abstract}
A B S T R A C T
Non-specific mechanisms involving ATP-binding cassette drug efflux transporters may play an important role in xenobiotic clearance in ovine gastro-intestinal nematodes. By using transporter inhibitors, the aim of this trial was to assess the possibility of increasing drug bioavailability in the host in an attempt to improve treatment efficacy. Thirty-six lambs were infected with 5000 multiple-drug resistant Haemonchus contortus third stage larvae and separated into six groups $(n=6)$ : ivermectin alone (IVM; $0.2 \mathrm{mg} / \mathrm{kg}$ body-weight, BW), ketoconazole alone (KET; $10 \mathrm{mg} / \mathrm{kg}$ BW), Pluronic 85 alone (P85; $4 \mathrm{mg} / \mathrm{kg}$ BW), IVM + KET, IVM + P85 or untreated control. Ivermectin was administered once on day 28 post-infection for all appropriate groups, whereas KET and P85 were administered as five separate doses on day 26-30 post-infection inclusive. The resultant data showed that concomitant administration of KET or P85 with IVM induced increases in plasma and tissue concentrations of IVM in treated animals, resulting in a two-fold increase in the area under the time-concentration curve $(p<0.05)$. Faecal egg counts and worm burdens of the IVM + KET and IVM + P85 groups were lower than in the untreated, KET and P85 alone control animals. Worm burdens were reduced by between $16 \%$ and $51 \%$ with IVM + KET and IVM + P85 respectively compared to untreated control animals. The co-administration of P85 with IVM increased the efficacy by $34 \%$, compared with IVM alone, in terms of worm count reduction of the multi-resistant isolate of $H$. contortus.
\end{abstract}

(c) 2012 Elsevier B.V. All rights reserved.

\section{Introduction}

The emergence of nematodes resistant to macrocyclic lactones (ML) threatens to severely limit current parasite control strategies. Macrocyclic lactones resistance appears to be multifactorial (Prichard and Roulet, 2007); mutations in a subunit of the glutamate-gated channel, changes in amphidial neuron structure, non-specific mechanisms

\footnotetext{
* Corresponding author. Tel.: +44131445 5111; fax: +44 1314456235.

E-mail address: clave.bartley@moredun.ac.uk (D.J. Bartley).
}

that control the final concentration of anthelmintic in the parasite are all thought to be determinants for efficacy of the drug and for the acquisition of resistance (reviewed by Wolstenholme et al., 2004). Macrocyclic lactones are poorly metabolised by cytochrome P450, and it appears that cytochrome P450 is not involved in ML. resistance in field nematodes (Alvinerie et al., 2001). However, it has become evident from molecular, biochemical and pharmacokinetic studies that the drug transporters involved in multi-drug resistance control the efflux of MLs out of the host and that they are playing a role in the ML resistance in the worm certainly by limiting drug 
accumulation in parasites (Lespine et al., 2008; Bartley et al., 2009; James and Davey, 2009). Efforts are being made to elucidate the roles of these efflux transporters in the development of anthelmintic resistance. Mechanisms under investigation include improved/enhanced expression levels of influx/efflux pumps such as P-glycoproteins (Pgp) (Kerboeuf et al., 2003; Prichard and Roulet, 2007).

P-glycoprotein is a membrane protein that belongs to the superfamily of the ATP-binding cassette $(A B C)$ transporters and more specifically to the multi-drug resistance proteins (Borst et al., 1999). It is expressed, in mammals, in a number of tissues such as the intestine, liver, brain as well as in haematological cells (Thiebaut et al., 1987). The main function of Pgp is the ATP-dependent efflux of various structurally unrelated exogenous compounds (Pouliot et al., 1997). In contrast to mammals that only have one or two Pgp genes, genes encoding Pgps are numerous in nematodes; for example, Caenorhabditis elegans has 14 genes (Lincke et al., 1992) and Haemonchus contortus may have a similar number. The products of these genes appear to play an important role in the protection of parasite neurones against anthelmintic molecules (Prichard and Roulet, 2007). P-glycoproteins have been implicated in resistance to broad spectrum anthelmintics; the benzimidazoles (Beugnet et al, 1997; Kerboeuf et al., 2002), and MLs (Xu et al., 1998), although little is known about Pgp function in parasitic nematodes. Work examining the inhibition of $A B C$ transporters (Lespine et al., 2007; Bartley et al., 2009) and cytochrome P450 (CYP; Kotze et al., 2006) activities in vitro via the use of specific interfering compounds such as verapamil hydrochloride (VER), ketoconazole (KET) and rotenone has been reported. These studies have demonstrated that in tests assessing larval feeding or development, it is possible to increase the sensitivity of gastrointestinal nematodes to anthelmintics with reversing agents. These in vitro results suggest that nonspecific mechanisms may assist the larvae to resist the toxic action of MLs and benzimidazoles in the parasite isolates examined.

The incorporation of $\mathrm{ABC}$ transporter and/or $\mathrm{CYP}$ inhibitors with chemotherapeutic agents in vivo has been conducted. Preliminary work is encouraging with significantly higher plasma ML concentrations being observed in non-parasitised sheep that were co-administered loperamide (Lifschitz et al., 2002), quercetin (Dupuy et al., 2003), VER (Molento et al., 2004; Pérez et al., 2010) or itraconazole (Ballent et al., 2007) with ivermectin (IVM) or moxidectin (MOX) compared to individuals administered ML alone. The use of KET in combination with IVM doubled the AUC for this product in dogs (Hugnet et al., 2007). Because the concentration of ML in plasma is directly related to drug efficacy, these results strongly suggest that ML co-administration with Pgp inhibitors will improve anthelmintic efficacy. Few studies have been performed in vivo to examine the effect of Pgp inhibitor co-administration on anthelmintic efficacy. In sheep, work to investigate the co-administration of IVM with loperamide (Lifschitz et al., 2010a,b), triclabendazole and piperonyl butoxide (Virkel et al., 2009) increased systemic availability of anthelmintic and, in the case of loperamide, an improvement in efficacy. On the basis of our previous work showing that ketoconazole (KET) and Pluronic P85 (P85) were able to reverse resistance in nematode in vitro (Bartley et al., 2009), the aim of this study was to assess the in vivo effect of co-administration of KET, a Pgp and CYP inhibitor (Sandström et al., 1999), and P85, a Pgp inhibitor, on the pharmacokinetics of IVM and the efficacy of this anthelmintic against $H$. contortus infection in sheep.

\section{Materials and method}

\subsection{Ethical approval}

All experimental procedures described in this manuscript were examined and approved by the Moredun Research Institute Experiments and Ethics Committee and were conducted under approved British Home Office licenses in accordance with the Animals (Scientific Procedures) Act of 1986 . The Home Office licence number is PPL 60/03899 and experimental code identifier was E07/13.

\subsection{Experimental design}

Table 1 contains details of the trial design including the time-scale for treatment and necropsy. In brief, thirty-six, 6-month-old Suffolk Greyface-cross parasite naïve lambs (20 males and 16 females) were challenged with 5000 infective larvae $\left(\mathrm{L}_{3}\right)$ of a multiple resistant isolate of $\mathrm{H}$. contortus (White River strain designated as $\mathrm{MHco} 4$ throughout the rest of the manuscript; Van Wyk and Malan, 1988). Previous work had shown that the isolate was highly resistant to IVM, with less than a $50 \%$ reduction in worm burdens compared to untreated controls when treated at $0.8 \mathrm{mg} / \mathrm{kg}$ body weight (BW; unpublished data).

Faecal egg counts (FEC) were conducted prior to the start of the trial to confirm worm-free status. On day 25 post-infection (PI), lambs were weighed and FEC determined to allow allocation of the animais into six groups matched on FEC, weight and, where possible, sex. The lambs were allocated into either an untreated control, IVM only (IVM; Oramec ${ }^{\circledR}, 0.2 \mathrm{mg} / \mathrm{kg}$ BW, Merial), KET only control (KET; $10 \mathrm{mg} / \mathrm{kg} \mathrm{BW}$, ICN Biomedical), P85 only control (P85; $4 \mathrm{mg} / \mathrm{kg}$ BW Sigma Aldrich), IVM + KET or IVM + P85 groups (treatments administered at rates as stated earlier). Both the KET and P85 compounds were suspended in distilled water and administered once daily to the appropriate groups per os by syringe on days 26-30 PI inclusive. Ivermectin was administered orally once on day 28 PI for all appropriate groups, i.e., the IVM, IVM + KET and IVM + P85 groups. On the basis of previous work (Ballent et al., 2007) KET or P85 were administered orally once daily over five days (two days prior to the administration of the IVM and two days after) in order to maintain inhibitor concentration at levels in the host in order to maximise interaction with IVM. The two compounds have different disposition in the plasma with short persistence when compared with IVM that has an especially long residence time in the host organism. Combination treatments were, where necessary, administered sequentially within a minute of each other. 
Table 1

Trial designs for the controlled efficacy tests including; treatment regime, number and sex of lambs per group, infective dose of White River isolate of Haemonchus contortus (MHco4), timings of treatment(s) and necropsy (P.M.).

\begin{tabular}{|c|c|c|c|c|c|c|c|c|}
\hline \multirow[t]{2}{*}{ Treatment } & \multirow[t]{2}{*}{$n / \operatorname{sex}$} & \multirow[t]{2}{*}{ Dose $\left(L_{3}\right)$} & \multicolumn{6}{|c|}{ Day post infection } \\
\hline & & & 26 & 27 & 28 & 29 & 30 & 35 \\
\hline Control - untreated & $3 / \mathrm{M} 3 / \mathrm{F}$ & 5000 & - & - & - & - & - & PM \\
\hline Pfuronic P85 (P85) & $4 / \mathrm{M} 2 / \mathrm{F}$ & 5000 & a & $a$ & a & a & a & PM \\
\hline Ketoconazole $(\mathrm{KET})^{b}$ & $4 / \mathrm{M} 2 / \mathrm{F}$ & 5000 & $b$ & $\mathrm{~b}$ & $\mathrm{~b}$ & $b$ & $\mathrm{~b}$ & PM \\
\hline Ivermectin (IVM) ${ }^{c}$ & $3 / \mathrm{M} 3 / \mathrm{F}$ & 5000 & - & - & c & - & - & PM \\
\hline $\mathrm{IVM}^{\mathrm{c}}+\mathrm{P} 85^{\mathrm{d}}$ & $3 / \mathrm{M} 3 / \mathrm{F}$ & 5000 & a & $\mathrm{a}$ & $\mathrm{ac}$ & a & a & PM \\
\hline IVM $^{c}+\mathrm{KET}^{\mathrm{b}}$ & $3 / \mathrm{M} 3 / \mathrm{F}$ & 5000 & $\mathrm{~b}$ & $\mathrm{~b}$ & bc & $b$ & $\mathrm{~b}$ & PM \\
\hline
\end{tabular}

$\mathrm{M} \rightarrow$ male; F - female; PM - post mortem. Anthelmintic and inhibitors when used alone or as part of a combination with inhibitors administered at dose rates of:

a Pluronic P85 (4 mg/kg):

Ketoconazole $(10 \mathrm{mg} / \mathrm{kg})$;

c Jvermectio $(0.2 \mathrm{mg} / \mathrm{kg})$.

The treatments were not mixed prior to being administered to the lambs.

\subsection{Samples collected}

Faecal samples were taken per rectum throughout the course of the trial and FEC conducted using a modification of the technique described by Jackson (1974). Venous blood was collected via jugular venepuncture into $10 \mathrm{ml}$ heparinised Vacutainer tubes (Becton Dickinson vacutainers systems) at $0,4,8,24,48,120,144$ and $168 \mathrm{~h}$ post administration of IVM. The samples were immediately centrifuged at $1272 \times \mathrm{g}$ for $15 \mathrm{~min}$; plasma was recovered and stored at $-20^{\circ} \mathrm{C}$ prior to analysis. Abomasal tissue folds and mucosal scrapings were collected at necropsy and stored at $-20^{\circ} \mathrm{C}$ for tissue IVM concentration determination.

\subsection{Necropsy and worm recovery}

All of the animals were necropsied on day 35 PI using the post mortem and worm recovery methods described previously (Patterson et al., 1996). The total worm burdens were estimated from a $2 \%$ sub-sample of the abomasal washings and saline digests. Recovered worms were staged using the development criteria described by Ministry of Agriculture Fisheries and Food (1986). Two folds were excised from along the central line of the greater curvature of the abomasa to provide material for tissue and mucus IVM concentration estimations. Twenty, randomly selected female worms from each individual animal, where available, were photographed (Leica DFC490) and measured using Image-Pro Express for windows (2003; Media Cybernetics).

\subsection{Ivermectin concentration and kinetic analysis}

Ivermectin concentrations were determined in plasma, abomasal tissue and mucus by high performance liquid chromatography (HPLC) with fluorescence detection according to previously described and validated methods (Alvinerie et al., 1998). Data were analysed using a noncompartmental approach with version 4.2 of the Kinetica Tm computer program (InnaPhase, Philadelphia, USA). The partial area under the plasma concentration-time curve
(AUC) from $t_{0}$ to $t_{168 \mathrm{~h}}$ was calculated by the linear trapezoidal rule. $T_{1 / 2}$, half life of elimination, and $C_{\max }$, maximal concentration, were then determined. Data are expressed as mean \pm standard error of the mean (SEM).

\subsection{Statistical analysis}

Worm burdens and FEC were square-root transformed to stabilise the variance prior to analysis (Kolmogorov-Smirnov, $P>0.05$ ). A repeated measure analysis with first-order power model was employed to model the FEC data of individual lambs over the course of the trial. The transformed FEC at day 26 was included as covariate in the model and considered as the baseline. The model included treatments and days post treatment as fixed effects. The parameters in the model were estimated using the REML directive (GenStat version 11, VSN International) and $P$ values were estimated using the modified F-statistics. The worm burdens were analysed with a linear model under the analysis of variance framework considering the treatment and gender of the worm as fixed effects. The percentage efficacy (P.E.) of the treatment was calculated in the controlled efficacy test using the equation: $(1-(T / C)) \times 100$, where $C$ and $T$ are the arithmetic mean total worm burdens of the control and treated groups respectively (Coles et al., 1992). Statistical analysis for the comparison of mean AUC values was performed using oneway ANOVA followed by Fisher's least significant difference (LSD) test (Statview software, Abacus concepts, Berkeley, CA, USA), Statistical significance was accepted as $p<0.05$.

\section{Results}

\subsection{Ivermectin concentration in plasma and in abomasal tissue}

Fig, 1 shows the mean plasma concentrations versus time of IVM after oral administration of IVM alone or co-administered with KET or with P85 (semilogarithmic scale). In all three groups, IVM was detected in the plasma until seven days post treatment, corresponding to the last sampling time. Concomitant administration of KET or P85 induced substantial increases in plasma concentrations of IVM resulting in a significant increase in the AUC $(p<0.05$, 


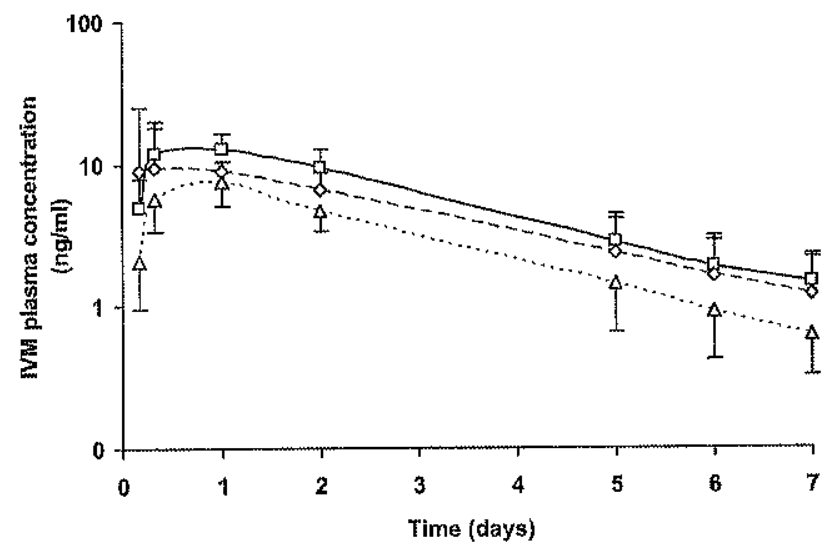

Fig. 1. Semilogarithmic plasma profile of ivermectin concentration in sheep infected with Haemonchus contortus (MHco4) and treated orally at time 0 with IVM alone $(0.2 \mathrm{mg} / \mathrm{kg} \mathrm{BW,})$ or co-administered with Pluronic P85 (4 mg/kg BW, $\diamond)$ or ketoconazole $(10 \mathrm{mg} / \mathrm{kg} \mathrm{BW}, \square)$. Inhibitors were administered on clays $26,27,28,29$ and 30 post-infection. Values are mean \pm S.D. of 6 animais.

Table 2). The $t_{1 / 2}$ of IVM, which is the half-life of elimination of the compound, was unchanged by co-treatment, whilst the $C_{\max }$ was increased after co-administration of KET or P85. The increase of $C_{\max }$ was statistically significant for IVM + P85 when compared with IVM alone $(p<0.05)$. At seven days post-treatment, in both the IVM $+P 85$ and IVM + KET groups, there was on average a two-fold increase of IVM concentration in mucosal scrapings and in abomasal tissue but these changes were not significant because of the high variability of drug concentration in those tissues (Fig. 2).

\subsection{Parasitology}

\subsubsection{Controlled efficacy test}

The average percentage establishment of the isolate was $65 \%$ (3233 worms), 65\% (3242 worms) and 48\% (2408 worms) in the untreated, P85 and KET control lambs respectively. Treatment with IVM, IVM + P85 and IVM + KET resulted in reductions in average total worm burden of $16 \%, 51 \%$ and $16 \%$, respectively, compared to untreated controls (Table 3). IVM + P85 treatments improved mean total worm burden reductions by $34 \%$ and $51 \%$ compared to IVM and P85 alone, respectively, whereas combinations of IVM + KET showed no improvement compared to IVM alone. The treatment had marginal statistically significant

\section{Table 2}

Pharmacokinetic parameters of ivermectin after oral administration in sheep. Sheep were infected with Haemonchus contortus (MHco4) and treated on day 28 post infection (PI) with a single dose of ivermectin (IVM) alone $(0.2 \mathrm{mg} / \mathrm{kg}$ BW) or co administered with Pluronic P85 (4 mg/kg BW) or ketoconazole $(10 \mathrm{mg} / \mathrm{kg}$ BW). Inhibitors were administered on days $26,27,28,29$ and $30 \mathrm{PI}$. Data are expressed as group average $(n=6)$. Values \pm standard error of the mean (S.E.M.).

\begin{tabular}{llcl} 
& AUC $(\mathrm{ngd} / \mathrm{ml})$ & $C_{\mathrm{max}}(\mathrm{ng} / \mathrm{ml})$ & $T_{1 / 2}(\mathrm{~d})$ \\
\hline IVM alone & $22.4 \pm 3.0$ & $7.5 \pm 2.4$ & $1.6 \pm 0.2$ \\
IVM + Pluronic P85 & $42.1 \pm 7.5^{\mathrm{a}}$ & $23.1 \pm 7.7^{\mathrm{a}}$ & $1.7 \pm 0.3$ \\
IVM + Ketoconazole & $43.2 \pm 6.8^{\mathrm{a}}$ & $15.1 \pm 2.0$ & $1.8 \pm 0.3$ \\
\hline
\end{tabular}

a $p<0.05$ versus IVM alone.

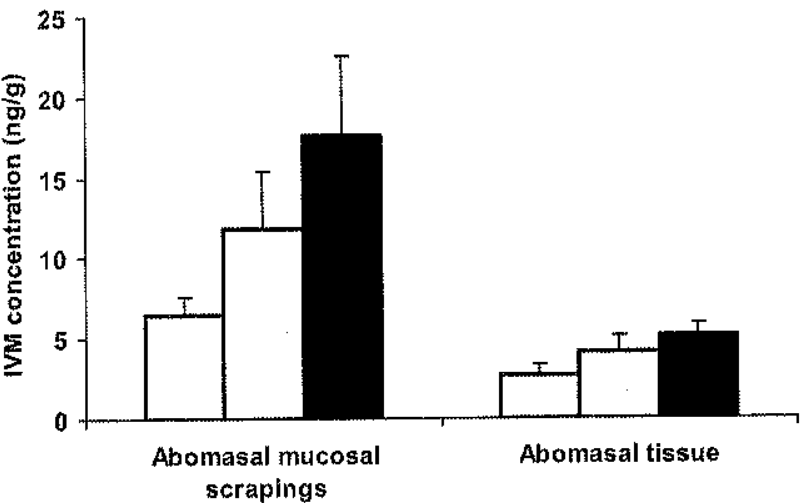

Fig. 2. Ivermectin concentration in abomasal mucosal scrapings and abomasal tissue seven days post-treatment in Haemonchus contortus (MHco4) infected sheep orally treated with ivermectin alone (IVM alone; $0.2 \mathrm{mg} / \mathrm{kg}$ BW, white bars) or co-administered with Pluronic P85 (P85; $4 \mathrm{mg} / \mathrm{kg} \mathrm{BW}$, grey bars) or ketoconazole (KET; $10 \mathrm{mg} / \mathrm{kg}$ BW, black bars). Inhibitors were administered on days $26,27,28,29$ and 30 post-infection. Data are mean \pm S.E.M. of 6 animals.

effect on the numbers of male $(P=0.049)$ and female $(P=0.060)$ parasites as well as the total parasitic count $(P=0.049)$. Although IVM $+P 85$ resulted in the greatest improvement in efficacy this did not differ significantly from the lambs treated with IVM alone. Treatment did not significantly alter female worm lengths (Table 3), with the exception of the KET groups in which female worms were found to be smaller than the untreated and IVM group worms $(p<0.05)$ and the P85 worms that were smaller $(p<0.05)$ than the untreated group.

\subsubsection{Faecal egg count reduction}

Prior to the administration of any treatment (day 26 PI), the average FEC of all animals was 3957 (range 3067-4604) eggs per gram. Twenty-four hours following administration of the inhibitors there appeared to be suppression in egg output and this continued until day $30 \mathrm{PI}$ (Fig. 3). After the initial suppression in egg output, the mean FEC of all groups rose steadily for the next five

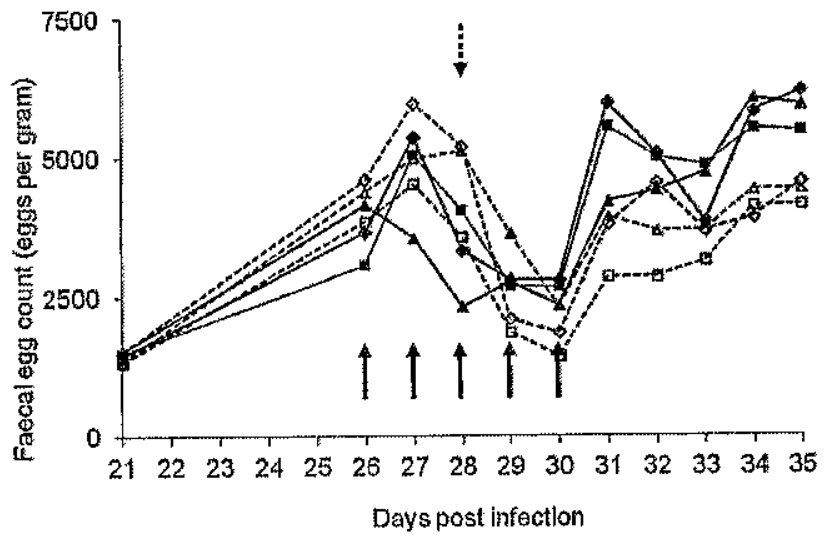

Fig. 3. Arithmetic mean faecal egg counts of the six groups of lambs 21-35 days post-infection with 5000 Haemonchus contortus (MHco4) infective larvae. The groups are untreated control $(\wedge)$; ivermectin alone (IVM, $\Delta$ ); Pluronic P85 alone (P85, $)$; ketoconazole alone (KET, E): IVM+P85 ( $\diamond)$ and IVM + KET ( $\square$ ). Ivermectin treatment, $\mathbf{f}$ inhibitor treatment. 
Table 3

Arithmetic mean ( \pm S.E.M.) Haemonchus contortus (MHco4) worm counts, range of counts, differentiation of worm burdens into males and female worms, and percentage efficacy (P.E.) of anthelmintic treated groups of sheep relative to untreated control lambs seven days post-treatment,

\begin{tabular}{|c|c|c|c|c|c|c|c|}
\hline \multirow[t]{2}{*}{ Treatment } & \multicolumn{3}{|c|}{$\begin{array}{l}\text { Arithmetic mean worm } \\
\text { burden ( } \pm \text { S.E.M.) [range] }\end{array}$} & \multirow[t]{2}{*}{ M:Fratio } & \multirow{2}{*}{$\begin{array}{l}\text { Average female worm } \\
\text { length (mm } \pm \text { S.E.M.) } \\
\text { [number] }\end{array}$} & \multirow[t]{2}{*}{$\begin{array}{l}\text { Per capita } \\
\text { fecundity }{ }^{\circ} *\end{array}$} & \multirow[t]{2}{*}{$\begin{array}{l}\text { Percentage } \\
\text { efficacy (P.E.) }\end{array}$} \\
\hline & Male & Female & Total & & & & \\
\hline Untreated & $\begin{array}{l}1692( \pm 186) \\
{[950-2300]}\end{array}$ & $\begin{array}{l}1542( \pm 129) \\
{[1000-1850]}\end{array}$ & $\begin{array}{l}3233( \pm 307) \\
{[1950-4100]}\end{array}$ & 1.1 & $\begin{array}{l}19.8 \pm 0.1 \\
{[120]^{] a c}}\end{array}$ & 4 & $\mathrm{NA}$ \\
\hline Ivermectin (IVM) & $\begin{array}{l}1200( \pm 146) \\
{[800-1700]}\end{array}$ & $\begin{array}{l}1500( \pm 249) \\
{[650-2400]}\end{array}$ & $\begin{array}{l}2700( \pm 351) \\
{[1450-4100]}\end{array}$ & 0.9 & $\begin{array}{l}19.7 \pm 0.1 \\
{[110]^{\mathrm{ac}}}\end{array}$ & 4 & 16 \\
\hline Pluronic P85 (P85) & $\begin{array}{l}1550( \pm 207) \\
{[800-2250]}\end{array}$ & $\begin{array}{l}1692( \pm 295) \\
{[400-2350]}\end{array}$ & $\begin{array}{l}3242( \pm 494) \\
{[1200-4600]}\end{array}$ & 1.1 & $\begin{array}{l}19.4 \pm 0.1 \\
{[105]^{\mathrm{bx}}}\end{array}$ & 5 & 0 \\
\hline Ketoconazole (KET) & $\begin{array}{l}1267( \pm 210) \\
{[300-1650]}\end{array}$ & $\begin{array}{l}1142( \pm 101) \\
{[850-1550]}\end{array}$ & $\begin{array}{l}2408( \pm 292) \\
{[1150-3200]}\end{array}$ & 1.1 & $\begin{array}{l}18.7 \pm 0.2 \\
{[112]^{b}}\end{array}$ & 8 & 26 \\
\hline$[V M+P 85$ & $\begin{array}{l}858( \pm 213) \\
{[200-1400]}\end{array}$ & $\begin{array}{l}742( \pm 237) \\
{[100-1600]}\end{array}$ & $\begin{array}{l}1600( \pm 438) \\
{[300-2900]}\end{array}$ & 1.6 & $\begin{array}{l}19.6 \pm 0.2 \\
{[72]^{\mathrm{dc}}}\end{array}$ & 3 & 51 \\
\hline IVM + KET & $\begin{array}{l}1483( \pm 138) \\
{[900-1850]}\end{array}$ & $\begin{array}{l}1217( \pm 232) \\
{[550-1850]}\end{array}$ & $\begin{array}{l}2700( \pm 335) \\
{[1650-3650]}\end{array}$ & 1.4 & $\begin{array}{l}19.7 \pm 0.2 \\
{[102]^{\text {ac }}}\end{array}$ & 7 & 16 \\
\hline
\end{tabular}

NA: Not applicable.

Ratio based on arithmetic mean of individual counts.

* Estimate calculated using faecal egg count (eggs per gram) at post mortem divided by number of adult female worms.

abc Different subscripts within the worm length column denote statistical significant differences $(P<0.05)$.

Estimated using the control versus treated counts.

days. Seven days post-treatment, FEC were reduced by $0 \%$, $8 \%, 23 \%, 25 \%$ and $30 \%$ for P85; KET; IVM + P85; IVM and IVM + KET respectively, when compared to the untreated control groups (Table 4). The treatment had statistically significant effect $(P=0.003)$ on the $F E C$ in lambs. Although the FEC of the IVM+KET and IVM+P85 were lower, they did not differ significantly, from the IVM alone group. However, the mean FEC in IVM + P85 differed significantly from that of KET $(P=0.0004)$ and P85 $(P=0.009)$ alone.

\section{Discussion}

The results from this trial demonstrate that the coadministration of $\mathrm{P} 85$ or $\mathrm{KET}$, known $\mathrm{ABC}$ transporter inhibitors, with IVM showed a statistically significant increase in the kinetic disposition in plasma AUC of IVM and a trend to increasing of IVM concentrations in, mucous and abomasal tissues in parasitised lambs compared with those treated with IVM alone. The association of $A B C$ transporter inhibitors with chemotherapeutic agents have been shown to increase drug availability in the human (Pérez-Tomás, 2006) and veterinary fields. Significantly higher plasma ML concentrations were observed in non-parasitised sheep when Pgp and CYP inhibitors were co-administered with ML (Molento and Prichard, 1999; Lifschitz et al., 2002; Dupuy et al., 2003; Molento et al., 2004; Ballent et al., 2006; Alvinerie et al., 2008; Virkel et al., 2009) or benzimidazoles (Lanusse and Prichard, 1992; Benchaoui and McKellar, 1996) resulted in improved pharmacokinetic profiles compared to individuals administered the anthelmintics alone. Improvements made in anthelmintic disposition in various compartments of the host were found to correlate with enhanced treatment efficacies (Lanusse and Prichard, 1992), therefore, improvements in IVM plasma and tissue kinetics are expected to lead to the parasites being exposed to a more potent concentration of the drug and, one would

Table 4

Arithmetic mean (IS.E.M.) Haemonchts contortus (MHco4) faecal egg counts, range of counts, and percentage efficacy (P.E.) and 95\% confidence intervals of anthelmintic treated groups of sheep relative to untreated control lambs at day 28 and 35 post infection. Ivermectin treatment was administered on day 28 where appropriate, abcde Different subscripts within the columns denote statistical significant differences $\{p<0.05\}$.

\begin{tabular}{|c|c|c|c|}
\hline \multirow[t]{3}{*}{ Treatment } & \multicolumn{2}{|c|}{ Faecal egg counts (ㅍ.E.M.) [range] } & \multirow[t]{3}{*}{ P.E. $(95 \%$ C.I. $)$} \\
\hline & \multicolumn{2}{|c|}{ Days post infection } & \\
\hline & 28 & 35 & \\
\hline \multirow{2}{*}{ Uncreated } & $2333( \pm 457)$ & $5943( \pm 1182)^{\text {acte }}$ & \multirow[t]{2}{*}{-} \\
\hline & [1053-3726] & {$[3096-10,404]$} & \\
\hline Ivermectin (IVM) & $\begin{array}{l}5120( \pm 1863) \\
{[1098-13,572]}\end{array}$ & $\begin{array}{l}4428( \pm 507)^{\text {atrd }} \\
{[3186-6408]}\end{array}$ & $25.5(0,53)$ \\
\hline \multirow{2}{*}{ Pluronic P85 (P85) } & $3327( \pm 904)$ & $6191(=1802)^{\mathrm{d} e}$ & \multirow{2}{*}{$0.0(0.49)$} \\
\hline & {$[792-6426]$} & {$[2502-13,518]$} & \\
\hline Ketoconazole (KET) & $4047( \pm 1451)$ & $5471( \pm 1060)^{62}$ & \multirow{2}{*}{$8.0(0,48)$} \\
\hline \multirow[b]{2}{*}{$V M+P 85$} & {$[99-10,404]$} & {$[1485-9288]$} & \\
\hline & $5205( \pm 1374)$ & $4559(+1656)^{a b c}$ & \multirow{2}{*}{$23.3(0.67)$} \\
\hline \multirow[b]{2}{*}[VM]{$+K E T$} & {$[594-10,926]$} & {$[162-11,358]$} & \\
\hline & $3572( \pm 456)$ & $4146( \pm 670)^{b}$ & $30.2(0,59)$ \\
\hline
\end{tabular}


expect, lead to an improvement in efficacy. The challenge remains to find an efficient and safe reversing agent able to increase not only the concentration in the host but more importantly the efficacy against the parasite.

Despite the commonly observed significant increases in plasma ML concentrations in various efficacy trials, they have not always translated into statistically significant reductions in parasitological parameters in particular worm burdens in previous trials. Loperamide co-administered with ML improved treatment efficacy in naturally infected sheep (Lifschitz et al, 2010a) and cattle (Lifschitz et al., 2010b). The degree of improvement in treatment efficacies compared the anthelmintic treatment alone ranged from around $18 \%$ against a Trichostrongylus colubriformis population (Lifschitz et al., 2009), 27\% against a predominantly Cooperia population (Lifschitz et al., $2010 \mathrm{~b}$ ), to around a $72 \%$ improvement against a wholly IVM resistant $H$. contortus isolate (Lifschitz et al., 2010a). The results obtained in our study with co-administration of IVM and P85 were encouraging and compare favourably with these findings, with a $34 \%$ increase in efficacy compared to IVM alone and are in agreement with previous results reporting improved treatment efficacies of compounds administered with pluronics in humans and rodents (for review, see Sharma and Garg, 2010).

Pluronic block copolymer P85 is often used in drug formulation for greater permeabilizing ability (Batrakova et al., 1999), specifically when co-administered with a substrate of an ATP-dependent efflux mechanism (Batrakova et al., 1999, 2001). The reasons for IVM concentration improvements have been attributed to the capacity of P85 to bind to cell membranes, to alter microviscosity and to strongly inhibit Pgp activity (Kabanov et al., 2005). P85 has also been found to interfere with several other multi-drug resistance (MDR) mechanisms, multi-drug resistance proteins (MRP1 and MRP2), in addition to Pgp (Shaik et al., 2008), although the effects on the former are less than that seen against Pgp (Batrakova et al., 2003).

Ketoconazole and other imidazole derivatives are orally active broad-spectrum systemic antifungal agents used in veterinary medicine. They are well known inhibitors of cytochrome $\mathrm{P} 4503 \mathrm{~A}$ activity in human hepatic microsomes (Maurice et al., 1992) and increased the AUC of several Pgp substrate drugs (Ward et al., 2004; Kageyama et al., 2005) including IVM (Ballent et al., 2006; Hugnet et al., 2007), reducing the clearance of the drug. Although the IVM + KET group showed an increase in IVM AUC, as expected and similar to the one measured with P85 co-administration, no improvement of anthelmintic efficacy was observed. The lack of improvement in treatment efficacy in the IVM + KET group is intriguing because the concomitant administration of compounds that inhibits both Pgp and CYP activity leading to higher circulatory concentration of the co-administered drug and would be expected to lead to improved efficacy (Fischer et al., 1998, 2005). Thus, the different efficacy results obtained with KET and P85 suggest that ivermectin concentration in the host is not the only factor involved in the improvement of drug efficacy, but other effects on the nematodes and specifically on nematodes transporter's may also occur in vivo, in the presence of P85 that do not happen with KET.
The simplest explanation of why the P85 treatment combination improved anthelmintic efficacy whilst the IVM + KET one did not would be that there was insufficient inhibitor present at the appropriate time to influence the activity of the IVM, although the pharmacological parameters would indicate that the concentration of the anthelmintic was significantly higher in the IVM+KET group compared to the IVM alone group. There is the possibility that the inhibition of one defence mechanism may lead to the rapid activation of other systems such MRP1 and MRP2 or breast cancer resistance proteins (BCRP1) foilowing administration of xenobiotic compounds (Dantzig et al, 2003). Work in yeast and humans have demonstrated that defence mechanisms can be activated and up-regulated quickly under environmental stress compared with "normal" cellular circumstances (Lee et al., 2002; Luscombe et al., 2004). A further complication could be the activation of more than one superfamily of Pgp or concomitant expression of Pgp and/or CYP in response to treatment (Matheny et al., 2001). Pluronic P85 has also been found to interfere with several MDR mechanisms, MRP1 and MRP2, in addition to Pgp, whereas KET interferes with Pgp and CYP3A4. The possibility exists that MRP is more important than CYP in host and/or nematodes for handling xenobiotic stresses; MRP analogue expression is strongly induced in IVM resistant $C$. elegans (James and Davey, 2009). The possibility also exists that there may actually be a degree of competitive binding in/at the worm by KET resulting in lower concentrations of IVM in the parasite and therefore reduced worm mortality. It would greatly improve our understanding of the mechanisms involved in anthelmintic resistance if it was possible to identify how IVM kinetics are affected in the worm, in order to determine what effect that MDR resistance inhibitors are having. The effect at the level of the nematode could be due to a specific effect of P85 on the relevant nematode transporters rather than to improvement of IVM concentration in the host. Also, the mode of action receptors, which are like the $A B C$ transporters membrane proteins can be modulated by P 85 . These points require further investigation at the nematode level.

Individual treatment efficacies were variable within the trial, with individual IVM, IVM + KET and IVM +P85 efficacies ranging between $0-55 \%, 0-49 \%$, and $10-91 \%$ with median efficacies of 19,20 and $47 \%$, respectively. This was not totally unexpected because, although no work has been conducted with ruminants, the relationship between multi-drug resistant and/or CYP phenotype and expression can greatly influence the efficacy of administered xenobiotic compounds (Zeng et al., 1998) and is regulated independently resulting in varying protein concentration and enzymatic activity, between 6- and 11-fold among individuals (Lown et al., 1994). If this level of variability occurs in sheep, then this may help explain the difference in the treatment efficacies in the inhibitor groups seen in this trial. A further confounding factor in interpreting the results was that although not statistically significant there appeared to be gender differences observed in the hosts to the appropriate treatments. In pharmacological terms, there appeared to be differences between male and female hosts; one example being that the average IVM 
AUC figures for female hosts were $184 \%$ and $69 \%$ of those observed in male hosts for the IVM + P85 and IVM + KET groups, respectively. Host gender differences in response to drug administration have been reported in cattle (Janus and Antoszek, 2000), sheep (Cristofol et al., 1998; Capece et al., 2000; Hosking et al., 2010) and goats (Capece et al., 2009).

A further factor that may have strongly influenced the results was the use of the high resistant "White River strain" $H$. contortus isolate within the trial, the isolate is extremely refractory to IVM treatment, having been shown within the laboratory to be able to tolerate four times the recommended dose rate of IVM (unpublished data). With the isolate being extremely refractory to IVM treatment, it is very likely that the non-specific mechanisms of drug handling such as Pgp are only one component of the parasites arsenal for surviving IVM treatment but as is known, ML resistance in gastro-intestinal nematodes is complex and a number of other mechanisms have been put forward to explain the phenomenon (Wolstenholme et al., 2004). The work illustrates that once a parasite has developed an extremely high level of resistance to a particular compound that reversion back to fully effective treatment with that compound is unlikely even with the use of $A B C$ modulators, although at what level this occurs will vary from isolate to isolate.

The use of combinations, particular those containing multiple actives, and their ability to slow resistance is an area that has received much discussion recently. The debate centres on the degree of selection exerted on a population by the use of combination treatments compared to the use of singly administered treatments either solely until they are no longer efficacious or in an annual rotation but could be broadened to include the inhibitors of non specific mechanism in combination with presently available anthelmintic compounds. Combinations have frequently been shown to be extremely effective at controlling resistant populations (Anderson et al., 1988, 1991). Simulated mathematical models (Barnes et al, 1995; Leathwick, in press; Learmount et al., 2012) suggest that the use of combinations under the appropriate conditions will slow down the selection of resistance but that the effect is greatest when the initial frequency of resistance alleles is low and under conditions of modest/high refugia. Dogma would suggest that if the genes for resistance are cartied on two separate loci at low frequencies, then the likelihood of a single individual carrying both is small and this is reduced further if three compounds are used (Roush, 1993). The counter argument is that if parasites are exposed to two or more compounds simultaneously, then the selection pressures will force them into developing solid muitiple resistance or face extinction (Van Wyk, 2007, electronic debate), and this can be predicted to happen when compounds are both Pgp substrates. The results achieved with the IVM + P85 combination are encouraging and show that the efficacy of ML can be altered in vivo by administration of $A B C$ transport modulators. The apparent increased anthelmintic efficacy, obtained in this study, warrants further work to investigate the reversal of anthelmintic resistance in other host-parasites systems, and research at the level of the mechanisms in the nematodes.

\section{Acknowledgement}

The authors acknowiedge the support and assistance provided by the Bioservices and Parasitology Departments at Moredun Research Institute, Mintu Nath from Biomathematics and Statistics Scotland (BioSS) for assistance with statistical analysis and interpretation of results and to the Scottish Government Rural and Environment Research and Analysis Directorate (RERAD; www.scotland.gov.uk), and to the European Union (PARASOL, http://www.parasolproject.net/project/parasol.php) for their financial support.

\section{References}

Alvinerie, M., Dupuy, J., Eeckhoutte, C., Sutra, J.F., Kerboeuf, D., 2001. in vitro metabolism of moxidectin in Haenonchus contortus adult stages, Parasitol, Res. 87, 702-704.

Alvinerie, M., Dupuy, J., Kiki-Mvouaka, S., Sutra, J,F, Lespine, A., 2008. Ketoconazole increases the plasma levels of ivermectin in sheep. Vet. Parasitol. 157, 117-122.

Alvinerie, M., Escudero, E., Sutra, J.F., Eeckhoutte, C., Galtier, P. 1998. The pharmacokinetics of moxidectin after oral and subcutaneous administration to sheep. Vet. Res. 29, 113-118.

Anderson, N., Martin, P.J. Jarrett, R.G., 1988. Mixtures of anthelmintics; a strategy against resistance. Aust. Vet. J. 65, 62-64.

Anderson, N., Martin, P... Jarrett, R.G., 1991, the efficacy of mixtures of albendazole sulfoxide and levamisole against sheep nematodes resistant to benzimidazole and levamisole. Aust. Vet. J. 68, 127-132.

Ballent, M., Lifschitz, A., Virkel, G., Sallovitz, J.1 Lanusse, C., 2006. Modulation of the P-glycoprotein-mediated intestinal secretion of ivermectin: in vitro and in vivo assessments. Drug Metab. Dispos. 34 , 457-463.

Ballent, M., Lifschitz, A., Virkel, G., Sallovitz, J, Lanusse, C., 2007. Involvement of P-glycoprotein on ivermectin kinetic behaviour in sheep: itraconazolemmediated changes on gastrointestinal disposition, ]. Vet. Pharmacol. Ther، 30, 242-248.

Bartley, D.j., McAllister, H., Bartley, Y., Dupuy, J, Menez, C., Alvinerie, M., Jackson, F. Lespine, A., 2009. P.glycoprotein interfering agents potentiate ivermectin susceptibility in ivermectin sensitive and resistant isolates of Teladorsagia circumcincta and Haemonchus contortus. Parasitology. 136, 1081-1088.

Barnes, E.H., Dobson, R.J., Barger, I.A., 1995. Worm control and anthelmintic resistance: adventures with a model. Parasitol. Today $11,56-63$.

Batrakova, E.V., Li, S., Alakhov, V.Y, Elmquist, W.F., Miller, D.W., Kabanov, A.V, 2003. Sensitization of cells overexpressing multidrug-resistant proteins by Pluronic P85. Pharm. Res. 20, 1581-1590.

Batrakova, E.V., Li, S., Miller, D.W., Kabanov, A.V., 1999. Pluronic P85 increases permeability of a broad spectrum of drugs in polarized BBMEC and Caco-2 cell monolayers. Pharm. Res. 16, 1366-1372.

Batrakova, E.V., Miller, D.W., Li, S., Alakhov, V.Y., Kabanov, A.V., Elmquist, W.F, 2001. Pluronic P85 enhances the delivery of digoxin to the brain: in vitro and in vivo studies. J. Pharmacol, Exp. Ther. 296, 551-557.

Benchaoui, H.A., McKellar, Q.A., 1996. Interaction between fenbendazole and piperonyl butoxide: pharmacokinetic and pharmacodynamic implications. J. Pharm. Pharmacol, 48, 753-759.

Beugnet, F., Gauthey, M., Kerboeuf, D., 1997. Partial in vitro reversal of benzinidazole resistance by the free-living stages of Haemonchus contortus with verapamil. Vet. Rec. 141, 575-576.

Borst, P., Evers, R., Kool, M., Wijnholds, ]., 1999. The multidrug resistance protein family. Biochim. Biophys. Acta 1461, 347-357.

Capece, B.P., Castells, G., Perez, F., Arboix, M., Cristofol, C., 2000. Pharmacokinetic behaviour of albendazole sulphoxide enantiomers in male and female sheep. Vet. Res. Commun. 24, 339-348.

Capece, B.P.S., Afonso, S.M.S., Laz+iro, R., Harun, M., Godoy, C., Castells, G., Crist tifol, C, 2009. Effect of age and gender in the pharmacokinetics of albendazole and albendazole sulphoxide enantiomers in goats. Res. Vet. Sci. $86,498-502$.

Coles, G.C., Bauer, C., Borgsteede, F.H.M., Geerts, S., Klei, T.R., Taylor; M.A., Waller, P.J., 1992. World-Association-for-the-Advancementof-Veterinary-Parasitol. WAAVP methods for the detection of anthelmintic resistance in nematodes of veterinary importance. Vet. Parasitol, 44, 35-44. 
Cristofol, C., Navatro, M., Franquelo, C., Valladares, J.E., Arboix, M., 1998. Sex differences in the disposition of albendazole metabolites in sheep. Vet. Parasitol. 78, 223-231.

Dantzig, A.H., de Alwis, D.P., Burgess, M., 2003. Considerations in the design and development of transport inhibitors as adjuncts to drug therapy, Adv, Drug Deliv. Rev. 53, 133-150.

Dupuy, J., Lartieu, G., Sutra, J.F., Lespine, A., Alvinerie, M., 2003. Enhancement of moxidectin bioavailability in lamb by a natural flavonoid: quercetin. Vet. Parasitol. 112, 337-347.

Fischer, V., Rodriquez-Cascon, A., Heitz, F., Tynes, R., Hauck, C., Cohen, D. Vickers, A.E.M. 1998. The multidrug resistance modulator valspodar PSC 833 is metabolizcd by human cytochrome P450 3A. Implications for drug-drug interactions and pharmacological activity of the main metabolite, Drug Metab. Dispos. 26, 802-811, 1998 .

Fischer, V., Einolf, H.J, Cohen, D., 2005. Efflux transporters and their clinical relevance. Mini Rev. Med, Chem. 5, 183-195.

Hosking, B.C., Kaminsky, R., Sager, H., Karadzovska, D., Seewald, W. Giraudel, J.M., Vercruysse, J., 2010. The effect of sheep breed, age, and gender on the pharmacokinetics and efficacy of monepantel, an amino-acetonitrile derivative. Parasitol. Res. 106, 367-375.

Hugnet, C. Lespine, A., Alvinerie, M., 2007. Multiple oral dosing of ketoconazole increases dog exposure to ivermectin. J. Pharm. Pharm. Sci. $10,311-318$

Jackson, F, 1974. New technique for obtaining nematode ova from sheep faeces. Lab. Pract, 23, 65-66.

James, C.E., Davey, M.W., 2009. Increased expression of ABC transport proteins is associated with ivermectin resistance in the model nematode Caenorhabditis elegans. Int. J. Parasitol. 39, 213-220.

Janus, K., Antoszek, J., 2000. The effect of sex and age on caffeine pharmacokinetics in cattle. Res, Vet. Sci. 69, 33-37.

Kabanov, AV., Batrakova, E.V., Sriadibinatla, S., Yang, Z., Kelly, D.L., Yu, $V ., 2005$. Polymer genomics: shifting the gene and drug delivery paradigms. J. Control. Release 101 (1-3), 259-271

Kageyama, M., Namiki, H., Fukushima, H., Ito, Y., Shibata, N., Takada, K., 2005. In vivo effects of cyclosporin $A$ and ketoconazole on the pharmacokinetics of representative substrates for P..glycoprotein and cytochrome P450 (CYP) $3 \mathrm{~A}$ in rats. Biol. Pharm. Bull. 28, 316-322.

Kerboeuf, D. Blackhall, W. Kaminsky, R., Samson-Himmelstjerna, G, 2003. P-glycoprotein in helminths: function and perspectives for anthelmintic treatment and reversal of resistance. Int. J. Antimicrob. Agents 22, 332-346.

Kerboeuf, D, Guegnard, F, Le Vern, Y, 2002. Analysis and partial reversal of multidrug resistance to anthelmintics due to P-giycoprotein in Haemonchus contortus eggs using Lens culinar's lectin. Parasitol. Res $88,816-821$.

Kotze, A.C. Dobson, R.J., Chandler, D., 2006. Synergism of rotenone by piperonyl butoxide in Haemonchus contortus and Trichostrongylus colubriformis in vitro: potential for drug-synergism through inhibition of nematode oxidative detoxification pathways. Vet. Parasitol. 136 $275-282$.

Lanusse, C.E., Prichard, R.K., 1992. Methimazole increases the plasma concentrations of the albendazole metabolites of netobimin in sheep. Biopharm. Drug Dispos. 13, 95-103.

Learmount, J., Taylor, M.A., Bartram, D.J, 2012. A computer simulation study to evaluate resistance development with a derquantel-abamectin combination on UK sheep farms. Vet Parasitol., doi:10.1016/j.vetpar.2011.12.033.

Leathwick, D.M. Modelling the benefits of a new class of anthelmintic in combination. Vet. Parasitol., doi:10.1016/j.vetpar:2011.11.050.

Lee, T.I., Rinaldi, N.J., Robert, F., Odom, D.T., Bar-Joseph, Z., Gerber, G.K Hannett, N.M., Harbison, C.T., Thompson, C.M., Simon, I., Zeitlinger, J., Jennings, E.G., Murray, H.L., Gordon, D.B., Ren, B., Wyrick, J.J., Tagne J,B., Volkert, T.L., Fraenkel, E., Gifford, D.K., Young, R.A., 2002. Transcriptional regulatory networks in Saccharomyces cerevisiae. Science $298,799-804$

Lespine, A., Martin, S., Dupuy, J., Roulet, A., Pineau, T., Orlowski, S. Alvinerie, M., 2007. Interaction of macrocyclic lactones with $\mathrm{P}$ glycoprotein: structure-affinity relationship. Eur, J. Pharm. Sci. 30 , $84-94$

Lespine, A., Alvinerie, M., Vercruysse, J., Prichard, R.K, Geidhof, P., 2008. ABC transporter modulation: a strategy to enhance the activity of macrocyclic lactone anthelmintics. Trends Parasitol. 24 293-298.

Lifschitz, A., Entrocasso, C., Alvarez, L., Lloberas, M., Ballent, M., Manazza, G. Virkei, G. Borda, B. Lanusse, C, 2010a. Interference with Puglycoprotein improves ivermectin activity against adult resistant nematodes in sheep. Vet. Parasitol. 172 (3-4), 291-298.

Lifschitz, A., Entrocasso, C., Alvarez, L., Lloberas, M., Ballent, M., Manazza, ]., Virkel, G., Borda, B., Lanusse, C., 2009. P.glycoprotein modulation modifies ivermectin pharmacokinetics and its efficacy against resistant nematodes in lambs. J. Vet. Pharmacol. Ther. 32, 74.

Lifschitz, A., Suarez, V.H., Sallovitz, J., Criste!, S.L., Imperiale, F., Ahoussou, S., Schiavi, C., Lanusse, C., 2010 J. Cattle nematodes resistant to maciocyclic lactones: comparative effects of P-glycoprotein modulation on the efficacy and disposition kinetics of ivermectin and moxidectin. Exp. Parasitol. 125, 172-178.

Lifschitz, A., Virkel, G., Sallovitz, J., Imperiale, F., Pis, A., Lanusse, C., 2002. Loperamide-induced enhancement of moxidectin availability in cattle. J. Vet. Pharmacol. Ther. 25, 111-120.

Lincke, C.R., et al, 1992. The P-glycoprotein gene family of Caenorhabditis elegans. Cloning and characterization of genomic and complementary DNA sequences. J. Mol. Biol. 228, 701-711.

Lown, K.S. Kolar's, J.C., Thummel, K.E, Barnett, J.L., Kunze, K.L., Wrighton, S.A., Watkins, $P, B$, 1994. Interpatient heterogeneity in expression of CYP3A4 and CYP3A5 in small bowel Lack of prediction by the erythromycin breath test. Drug Metab. Dispos. 22, 947 955.

Luscombe, N.M., Babu, M.M. Yu, H.Y., Snyder, M., Teichmann, S.A., Gerstein, M., 2004. Genomic analysis of regulatory network dynamics reveals large topological changes. Nature 431, 308-312.

Matheny, C.J., Lamb, M.W., Kim, D., Brouwer, L.R., Pollack, G.M., 2001, Pharmacokinetic and pharmacodynamic implications of P-glycoprotein modulation. Pharmacotherapy 217, 778-796.

Maurice, M., Pichard, L., Daujat, M., Eabre, I., Joyeux, H., Domergue, J., Mauw rel, P. 1992. Effects of imidazole derivatives on cytochromes P450 from human hepatocytes in primary culture. FASEB J. 6, 752-758.

Ministry of Agriculture Fisheries Food, 1986. Manulal of Veterinary Parasitological Laboratory Techniques. Her Majesty's Stationery Office, London.

Molento, M.B., Lifschitz, A., Sallovitz, J., Lanusse, C., Prichard, R., 2004. Influence of verapamil on the pharmacokinetics of the antiparasitic drugs ivermectin and moxidectin in sheep. Parasitol. Res. 92, 121-127.

Molento, M.B., Prichard, R.K., 1999. Effects of the multidrug-resistancereversing agents verapamil and $\mathrm{CL} 347,099$ on the efficacy of ivermectin or moxidectin against unselected and drug-selected strains of Haemonchus contortus in jirds Meriones unguiculatus, Parasitol. Res. 85, 1007-1011.

Patterson, D.M., Jackson, F., Huntley, J.F., Stevenson, L.M., Jones, D.G. Jackson, E., RUSSEL, A.J.F., 1996, The response of breeding does to nematodiasis: segregation into "responders" and "non-responders". Int. J. Parasitol. 26, 1295-1303.

Pérez-Tomás, R., 2006. Multidrug resistance: retrospect and prospects in anti-cancer drug treatment. Curr. Med. Chem. 1316, 1859-1876.

Pérez, R., Palma, C., Núñez, M., Urrutia, P., Salazar, A., Morales, L., Vera, D., Cox, J., 2010. Influence of verapamil on pharmacokinetics and transplacental transfer of ivermectin in sheep Sm. Rum. Res. $93(2-3)$ $103-109$.

Pouliot, J.F., LHeureux, F., Liu, Z., Prichard, R.K., Georges, E., 1997, Reversal of P-glycoprotein-associated multidrug resistance by ivermectin. Biochem, Pharmacol. 53, 17-25.

Prichard, R.K., Roulet, A., 2007. ABC transporter's and beta-tubulin in macrocycilc lactone resistance: prospects for marker development. Parasitology 134, 1123-1132.

Roush, R.T., 1993. Occurrence, genetics and management of insecticide resistance. Parasitol. Today 9 (5), 174-179.

Sandström, R, Knutson, T.W., Knutson, L., Jansson, B., Lennernäs, H., 1999. The effect of ketoconazole on the jejunal permeability and CYP3A metabolism of R/S-verapamil in humans. Br. J. Clin. Pharmacol. 48 180-189.

Shaik, N., Pan, G., Elmquist, W.F., 2008. Interactions of pluronic block copolymers on P-gp efflux activity: experience with HIV-1 protease inhibitors. J. Pharm. Sci. 97, 5421-5433.

Sharma, P., Garg, S., 2010. Pure drug and polymer based nanotechnologies for the improved solubility, stability, bioavailability and targeting of anti-HIV drugs. Adv. Drug Deliv. Rev. 62, 491-502.

Thiebaut, F., Tsuruo, T., Hamada, H., Gottesman, M.M., Pastan, I., Willingham, M.C., 1987. Cellulat localization of the multidrug resistance gene product P $\rightarrow$ glycoprotein in normal human tissues. Proc. Natl. Acad. Sci. U.S.A. 84, 7735-7738.

Van Wyk, J.A, 2007. FAO-University of Pretoria Electronic Conference IV: Drugs in anthelmintic resistance management: to mix or not sometimes to mix - that's the question. Available at: http://cnia.inta.gov.ar/helminto/Foro\%2007/pretoria.htm.

Van Wyk, J.A., Malan, F.S., 1988. Resistance of field strains of Haemonchus contortus to ivermectin, closantel, rafoxanide and the benzimidazoles in South Africa. Vet. Rec, 123, 226-228.

Virkel, G., Lifschitz, A., Sallovitz, J., Ballent, M., Scarcella, S., Lanusse, C., 2009. Inhibition of cytochrome $\mathrm{P} 450$ activity enhances the systemic availability of triclabendazole metabolites in sheep. J. Vet. Pharmacol. Ther. $32,79-86$. 
Ward, K.W. SteIman, G.J., Morgan, J.A. Zeigler, K.S., Azzarano, L.M. Kehler, J.R., McSurdy-Freed, J.E., Proksch, J.W., Smith, B.R., 2004, Developmen of an in vivo preclinical screen model to estimate absorption and first-pass hepatic extraction of xenobiotics II. Use of ketoconazole to identify P-glycoprotein/CYP3A-limited bioavailability in the monkey. Drug Metab. Dispos. 32, 172-177.

Wolstenholme, A.J., Fairweather, l., Prichard, R, von SamsonHimmelstjerna, G., Sangster, N.C., 2004. Drug resistance in veterinary helminths. Trends Parasitol. 20, 469-476.
Xu, M, Molento, $M$, Blackhall, W, Ribeiro, B., Beech, R, Prichard, $R$., 1998 . Ivermectin resistance in nematodes may be caused by alteration of P-glycoprotein homolog. Mol, Biochem. Parasitol, 91, $327-335$.

Zeng, Z, Andrew, N.W., Arison, B.H., Luffer-Atlas, D., Wang, R.W., 1998. Identification of cytochrome P4503A4 as the major enzyme responsible for the metabolism of ivermectin by human liver microsomes. Xenobiotica 283, 313-321. 